\title{
Imágenes de la manipulación externa de un marcapasos por parte del paciente
}

\author{
Image of a pacemaker that was externally manipulated by the patient \\ Fernando D. Berdaguer Ferrari* y Julio Badie \\ Unidad de Terapia Intensiva, Hôpital Nord Franche-Comté, Trevenans, Francia
}

La figura 1 pertenece a una paciente de 77 años con antecedentes de trastornos psiquiátricos y neurocognitivos, múltiples consultas al servicio de urgencias e internaciones por causas sociales más que médicas. A ellos se suma la colocación de un marcapasos en marzo de 2018 por bradicardia en el contexto de un bloqueo auriculoventricular 2:1. En enero de 2019 la paciente es hospitalizada por debilidad general luego de un cuadro gastrointestinal; el ECG revela fibrilación auricular y signos de disfunción de sensado y captura del marcapasos de doble cámara, con espigas de marcapasos disociadas del ritmo de base del paciente (Fig. 2). Como puede observarse en la figura 1, la paciente muestra un desplazamiento de los cables del marcapasos, confirmado por ella misma, secundario a múltiples rotaciones sobre su eje por manipulación externa de éste, una alteración que se conoce como síndrome de twiddler ${ }^{1,2}$. Se le implanta un nuevo marcapasos al poco tiempo y la paciente recibe el alta (Fig. 3).

El síndrome de twiddler (dar vueltas en inglés) corresponde a una inusual falla del marcapasos consecutiva al desplazamiento de sus cables. Son pocos los informes de este suceso, las más de las veces relacionado con pacientes que sufren trastornos demenciales o psiquiátricos del tipo obsesivo-compulsivo y que se presentan a la consulta con cuadros diversos, desde episodios sincopales hasta contracciones involuntarias musculares en el tórax, o incluso casos asintomáticos. Otras variantes de la disfunción del marcapasos por

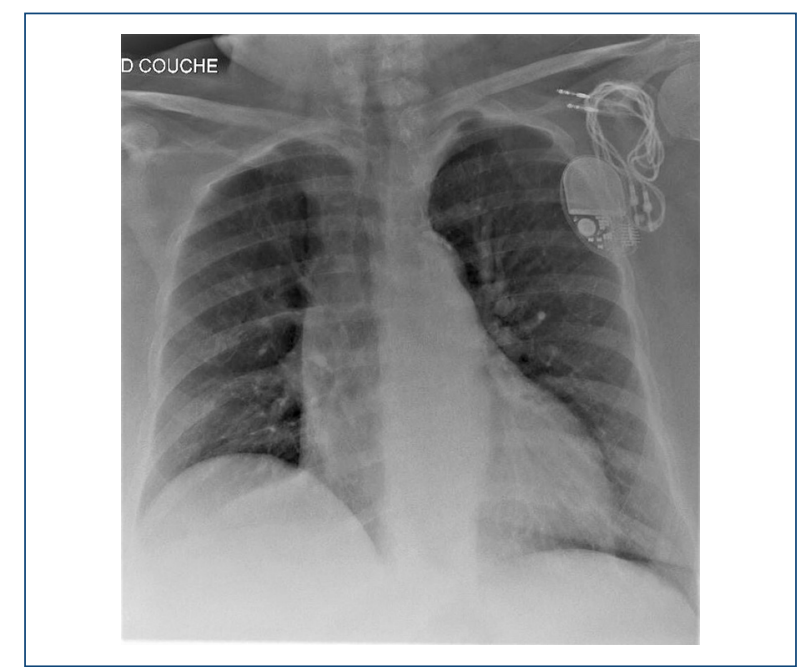

Figura 1. Radiografía de tórax de la paciente. Obsérvense en la región subclavicular izquierda los cables del marcapasos completamente fuera del corazón. D: derecha; couche: acostado en francés.

\section{Correspondencia:}

*Fernando D. Berdaguer Ferrari

E-mail: fberdaguer@hotmail.com
Disponible en internet: 12-04-2021 Arch Cardiol Mex. 2021;91(2):238-239 www.archivoscardiologia.com 1405-9940 / ๑ 2020 Instituto Nacional de Cardiología Ignacio Chávez. Publicado por Permanyer. Este es un artículo open access bajo la licencia CC BY-NC-ND (http://creativecommons.org/licenses/by-nc-nd/4.0/). 


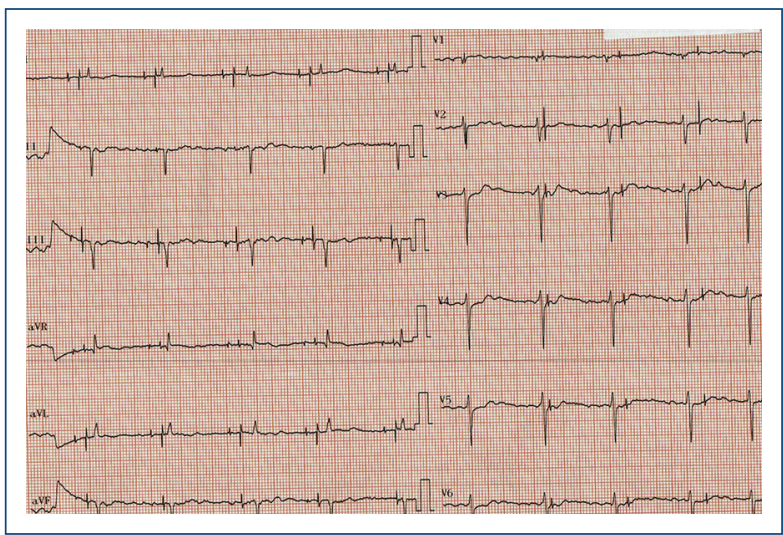

Figura 2. Electrocardiograma de la paciente al momento del ingreso que revela un ritmo de fibrilación auricular a $63 \mathrm{lpm}$, con espigas del marcapasos de doble cámara con defecto de sensado y captura del marcapasos de doble cámara.

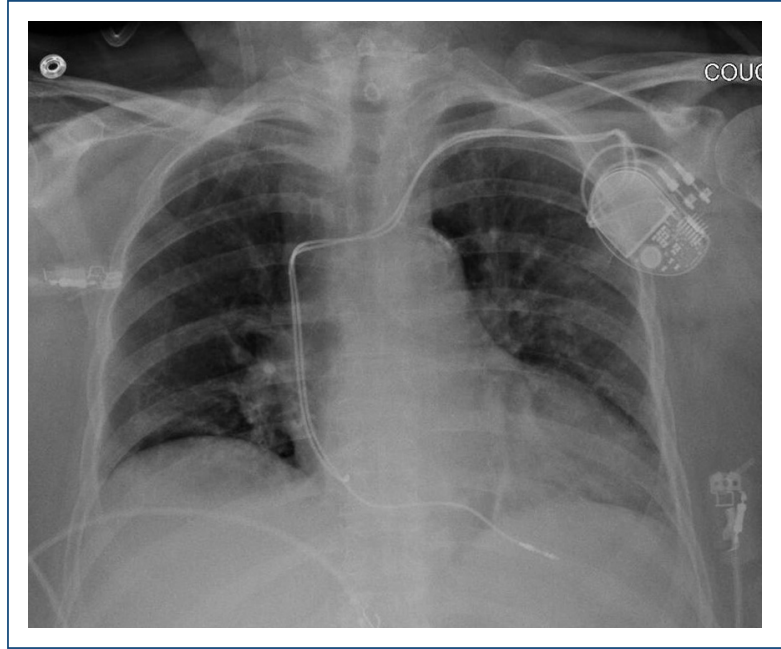

Figura 3. Radiografía de tórax luego de la colocación de un nuevo marcapasos. Couche: acostado en francés.

desplazamiento pueden ser el síndrome de reel (enrollamiento), en el cual el desplazamiento es también efecto de la manipulación externa, pero sobre el eje transversal, no sobre el eje largo como en el síndrome de twiddler, o el síndrome de rachet (trinquete), que no es consecuencia de la manipulación del paciente sino de movimientos habituales del brazo homolateral, junto con posibles defectos de fijación del generador, lo que propicia el desplazamiento de los cables $^{3}$.

\section{Financiamiento}

Esta investigación no ha recibido ninguna beca específica de agencias de los sectores público, comercial, o sin ánimo de lucro.

\section{Conflicto de intereses}

Los autores declaran no tener ningún conflicto de intereses.

\section{Responsabilidades éticas}

Protección de personas y animales. Los autores declaran que para esta investigación no se han realizado experimentos en seres humanos ni en animales.

Confidencialidad de los datos. Los autores declaran que han seguido los protocolos de su centro de trabajo sobre la publicación de datos de pacientes.

Derecho a la privacidad y consentimiento informado. Los autores declaran que en este artículo no aparecen datos de pacientes.

\section{Bibliografía}

1. Bayliss CE, Beanlands DS, Baird R. The pacemaker-ywiddler's syndrome: a new complication of implantable transvenous pacemakers. Canadian Medical Association Journal. 1968;24;99(8):371.

2. Castillo R, Cavusoglu $E$. Twiddler's syndrome: an interesting cause of pacemaker failure. Cardiology. 2006;105(2):119-21.

3. Arias MA, Pachón M, Puchol A, Jiménez-López J, Rodríguez-Picón B, Rodríguez-Padial L. Ordenación terminológica sobre macrodislocación de electrodos de dispositivos cardiacos electrónicos implantables. Revista Española de Cardiología. 2012;65(7):671-673. 